\title{
The Announcement Effect of Exchangeable Bonds in China
}

\author{
Xi Wang \\ School of Economics, Jinan University, Guangzhou, China \\ Email:907870314@qq.com
}

How to cite this paper: Wang, X. (2017) The Announcement Effect of Exchangeable Bonds in China. Technology and Investment, 8, 96-107.

https://doi.org/10.4236/ti.2017.82008

Received: April 20, 2017

Accepted: May 23, 2017

Published: May 26, 2017

Copyright (C) 2017 by author and Scientific Research Publishing Inc. This work is licensed under the Creative Commons Attribution International License (CC BY 4.0).

http://creativecommons.org/licenses/by/4.0/

\section{cc) (i) Open Access}

\begin{abstract}
The exchangeable corporate bonds have been so popular since entering China. Because the time is short, there are few empirical researches on the announcement effect of exchangeable bonds in China. Based on the event study method, the article carries the empirical study on the announcement effect of the exchangeable bonds which their target company's stocks are issued in China's A-share stock market. The results show that there is a negative influence on the market when the announcement announced. On the six days before the event day, the abnormal return is significantly positive, while it's negative on most of the other days, and is not significant. At the same time, the cumulative abnormal returns of each window period are not significant. The Shanghai A-share stock market may exist news leaked in advance, but once the news is disclosed, the market can digest the message soon, the stock price can return stable in a short time, so it is satisfied with the effective market. The validity of Shanghai A-share market will also need further enhance. It needs to speed up the improvement of the financial system, further refine trading rules, create rich financial derivatives for people to use, perfect the legal laws and regulations, focus on the regulations, and standardize China's financial market, so it can develop toward a good direction.
\end{abstract}

\section{Keywords}

Exchangeable Bonds, Announcement Effect, Event Study Method, Abnormal Return

\section{Introduction}

Exchangeable bonds (EB), refers to the shares holders issue corporate bonds, through mortgaging their holdings of stocks to the trustee. The holders of the bonds can with holding bonds for the mortgaged equity of listed companies in a certain period of time, according to the contract conditions. 
According to the different terms and conditions, exchangeable bonds can be divided into five categories, namely ordinary exchangeable bonds, bonus compensation type of exchangeable bonds, waiting type of exchangeable bonds, a basket of stocks exchangeable bonds and the exchangeable bonds which can pay at any time. Exchangeable bonds prospectus covers a variety of factors, including face value, coupon rate and maturity, the exchange price, exchange rate, exchange value and exchange period and so on. Some additional terms were agreed in the contract of exchangeable bonds, such as the redemption clauses, it refers to before the bond maturity, the issuer has the right to redeem exchangeable bonds early with the price according to the terms of agreement, and redemption price is generally higher than the face value of the exchangeable bonds. Putbacks terms, referring to safeguard clause, is also the lowest return exchangeable bonds. Revised terms refer to the issuer active downward revisions in share prices, under certain conditions. In addition, the exchangeable bonds also have the nature of stocks and bonds. It can not only bring the fixed income, but also can convert debt into equity. It is the bond investors' important channel to maintain flexibility and share the stock market returns.

For a long time, exchangeable bonds are the tools of capital markets in developed countries. The characteristics of exchangeable bonds are used by the CSRC to deal with all kinds of sizes financing needs, which are not belong to the equity holdings. Learn from the development of exchangeable bonds in European and American, CSRC studied the issuer, the underlying stocks, the issuing scale and the related terms. CSRC formulated and published the rule issuing exchangeable corporate bonds interim provisions for the shareholders of listed companies. China's exchangeable bonds issued for the first time in 2008, and the real development begins from the issue of the exchangeable bonds "13 Fuxin Debt" in the October 2013.

With the improvement of relevant laws and regulations, the quantity, type and scale of exchangeable bonds are constantly growing. In the year of 2013 to 2016, it has issued 66, 70 billion yuan, and become one of the most high-profile investment products. So far, the exchangeable bonds in China is no longer just for the underweight financing, but was given a new mission and new function, it is for revitalizing the major shareholders in equity capital. As a new financing tool, a new financial derivative and also a kind of new varieties for fixed-income investments, the development of exchangeable bonds is getting better and better.

\section{The Announcement Effect Theory and Literature Review}

Announcement effect refers to the release or happening of an economic or political events, which will affect another event. Announcement effect of exchangeable bonds refers to the disclosure of the announcement can bring fluctuation to stock prices for listed companies. The study is of great significance. Companies need to assess the influence of issuing exchangeable bonds or other financing tools on the fluctuation of stock price. Choose the most appropriate financing strategy in accordance with the long-term or short-term effect. While, in- 
vestors should also grasp the exchangeable bonds' announcement effect, and make the optimal choice of investment tools.

Announcement effect on the corporate debt can be divided into two aspects, the announcement effect of corporate debt with no choice and the announcement effect of corporate debt with choice.

\subsection{The Announcement Effect of General Corporate Debt, with No Choice}

Easterbrook (1984) [1], Flannery (1986) [2] and Kale and Noe (1990) [3] consider that the short-term debt financing company is high quality, while the company is the low quality of long-term bonds. So, if a company issuing bonds, it is a negative message to the market. Datta et al. (2000) [4] also think that the announcement of issuing bonds will be a negative signal to the stock market. Berlin M, and Loeys J. (1988) [5] and Diamond (1991) [6] have shown that the problem of information asymmetry consisted in the process of issuing convertible bonds. Compared with the bank and the shareholders, the information asymmetry between debt holders and shareholders will be more significant. So, the issuance of company bonds will be negative signals to the market, while the bank loan contract stamps will be positive signals to the market. Myers (1977) [7] explains the negative effect of the market to the corporate bonds issued announcement. He used model analysis and concluded that, compared to internal financing companies, the company's growth will be lower through issuing bonds to finance. The longer the term of companies issue bonds, the smaller of the growth. Shang, Y. H. (2009) [8] selected the ten bonds as research samples, which are issued by Shanghai market's listed companies in 2008. Analyzed the excess return of the ten bonds in a few days before and after the issue. It was found that, based on the bonds issue date t, the excess return of bond is positive during the time of $t-5$ to $t-1$. The conclusion is that companies issue bonds convey a positive signal to the market. Zhao C. (2016) [9] selected 102 companies which had announced to issue corporate bonds. The result showed that the abnormal returns were negative but not significant before the announcement. After the announcement, the CAR was negative in the consolidation range, but positive in ascending channel and descending channel.

\subsection{The Announcement Effect of General Corporate Debt, with Choice}

Abhyankar and Dunning (1999) [10] selected a variety of convertible securities as the research object, issued by the British between 1986 to 1996, and tested the wealth effect of publication. Through the test, they found that issued announcement on the underlying stock price will be a significant negative impact. Dutordoir and Van DE Gucht (2004) [11] studied the reaction of the issuer facing the convertible bonds company announcement issued by the western European. They found that on the day of the announcement day and the next day, the stock price showed obvious negative impact on the announcement effect. Manuel 
Ammann, Martin Fehr, Ralf Seiz (2006) [12] research the data of exchangeable bonds and convertible bond from 1996 to 2003 in Switzerland and Germany. They draw the conclusion that the bonds issue announcement will make the excess return of stock price to be negative. However, there are some scholars draw the opposite conclusion through analysis of the market outside the us. For example, Kang and Stulz (1996) [13] analyzed the effect of issue convertible company bonds announcement in the Japanese market. The study found that if the company issue convertible bonds in the Japanese market, their stock prices will have obvious positive effect to the issued announcement. De Roon and Veld (1998) [14] studied the effect of issuing Convertible-bond loans and Warrantbond loans announcement from 1976 to 1996 in the Netherlands Amsterdam Stock Exchange (AEX). The results show that the first is excess to the market, but the effect is not obvious. However, the second can produce a clear and positive excess to the market. Dutordoir et al. (2015) [15] use a global sample of convertible bonds issued from 1982 to 2012, they find that the announcement effect on convertible bonds in Japan is more significant than the announcement effect in other developed countries. The main reason lies in that Japan issues convertible bonds for capital expenditure, while America issues them for general use. Ammann, M., Blickle, K., \& Ehmann, C. (2017) [16] studied the announcement effects of convertible bonds issued by global banks between January 2009 and June 2014. They find positive abnormal stock returns after the announcement of convertibles bonds by using a sample of 34 financial institutions.

In China, Wang, H. Y. and Xia, X. P. (2004) [17] based on our securities market to sell and actual issuance of convertible bonds in the year 2000 to 2003, quantitatively analysis the announcement effect and its driving factors. Results show that after the announcement of planning to issue convertible bond, company's secondary market stock price declines significantly. While after the announcement of actually issuing convertible bond, the company's secondary market stock price rises significantly. Luo, Y., Wang, G. S. and Zhang, Z. C. (2006) [18], Chen, H., and Li, Y. X. (2005) [19] and Tao, Z. C. (2007) [20] researched on the announcement effect of the convertible bonds in China, based on event study, found that within the time window, the companies issuing convertible bonds had negative cumulative abnormal returns. Xu, X. Q. (2010) [21] chose the listed companies which used bond financing from Shanghai Stock Exchange and Shenzhen Stock Exchange as research objects, analyzed the company's financial data from 2006 to 2007, used principal component analysis to establish the comprehensive performance indicators, analyzed the relationship between debt financing and comprehensive performance. The results showed that it exits significant positive correlation between debt financing and comprehensive performance, and the former was of great benefit to the corporate governance. Fu, L. M., Wan, D. F. and Zhang, Y. H. (2011) [22] found that the convertible bond issued announcement has significant positive price effect. Wang, B., Miao, J. and Wang, F. (2014) [23] choose the convertible bonds of 50 listed companies in the A-share market of China as the research object and study 
their announcement effects. They get the conclusion that the action of issue convertible bonds will have significant negative effects. In addition, compared to the convertible bonds with warrants, the announcement effect of the ordinary convertible bonds is more significant.

Because China's exchangeable bond market has just started, Scholars in China research on China's exchangeable bonds only stay at theory stage. There are only researches on its pricing, term designing and legal system, accept the empirical study of exchangeable bonds' announcement effect. In order to fill the blank in this field, this paper combined with China's specific conditions and based on numerous domestic and overseas researches, used empirical study method to reach the reasonable explanations.

\section{The Empirical Analysis}

\subsection{Select the Research Methods}

1) The Definition of Events

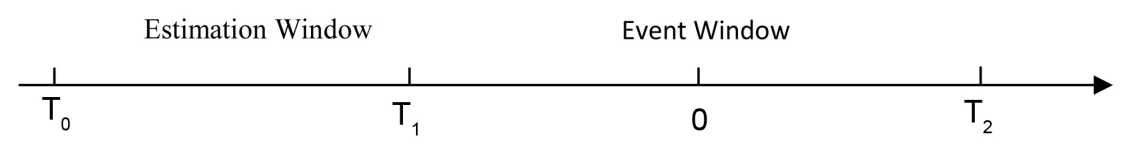

Defines $t=0$ as event day, $(-10,20)$ as the event window, $(-270,-10)$ as the estimation window in order to estimate the parameters. At the same time, select the window period of $(-1,1),(-1,0),(0,1),(-2,2),(-2,0),(0,2)$ for comparison, studies the announcement effect of issuing exchangeable bonds.

2) Definitions of Expected Return and Abnormal Return

a) Expected Return

The expected return refers to the estimated stock return of $T_{1}$ to $T_{2}$. Use $E R_{\text {it }}$ to represent the excepted return of stock $i$ in time $t$. Defines $L=T_{1}-T_{0}, L$ as the length of estimation window.

This paper makes an empirical analysis by using the market model. In the market model, assumes that there is a linear relationship between the expected return and the market return at the same time. So:

$$
E R_{i t}=\alpha_{i}+\beta_{i} R_{m t}
$$

Parameter estimation in market model:

When using the market model, estimate parameters to get the expected return by OLS. Within the appropriate estimation window:

$$
R_{i t}=\alpha_{i}+\beta_{i} R_{m t}+\varepsilon_{i t}, t=T_{0}+1, \cdots, T_{1}
$$

To get the expected return within event window, assume that the value of $\hat{\alpha}_{i}$ and $\hat{\beta}_{i}$ are stable before and after the event occurs.

$$
\hat{R}_{i t^{*}}=\hat{\alpha}_{t}+\hat{\beta}_{t} R_{m t^{*}}, t^{*}=T_{1}+1, T_{1}+2, \cdots, T_{2}
$$

b) Abnormal Return

Abnormal return is the actual return minus the expected return in stock market after the event occurs. Use $A R_{i t}$ as the abnormal return of stock $i$ in time $t$. 


$$
A R_{i t}=R_{i t}-\left(\alpha_{i}+\beta_{i} R_{m t}\right)
$$

3) Hypothesis Test for Abnormal Return and Cumulative Abnormal Return

a) Hypothesis Test for Abnormal Return

Test the abnormal return in the market model, the abnormal return within the event window is:

$$
A R_{i t^{*}}=R_{i t^{*}}-\hat{R}_{i t^{*}}
$$

Standardize the abnormal return:

$$
A \hat{R}_{i t^{*}}=\frac{A R_{i t^{*}}}{\sqrt{\operatorname{var}\left(A R_{i t^{*}}\right)}}
$$

$H_{0}: A R_{i t^{*}}=0 . A \hat{R}_{i t^{*}}$ obeys the $t$ distribution with the degrees of freedom for L-2. With the increase of degree of freedom, $t$ distribution is asymptotic to normal distribution, so $A \hat{R}_{i t^{*}}$ obeys normal distribution when the estimate window is long.

Defines the statistic:

$$
J_{1}=\left(\frac{N(L-2)}{L-4}\right)^{\frac{1}{2}} \frac{1}{N} \sum_{i=1}^{N} A \hat{R}_{i t^{*}}
$$

Under null hypothesis conditions, statistic $J_{1}$ obeys the standard normal distribution.

b) Cumulative Abnormal Return

Assume $T_{1}+1<t_{1}<t_{2}<T_{2}$, calculate the cumulative abnormal return of company $i$ within the period $\left[t_{1}, t_{2}\right]$ :

$$
\operatorname{CAR}_{i}\left(t_{1}, t_{2}\right)=\sum_{t^{*}=t_{1}}^{t_{2}} A R_{i t^{*}}
$$

The average cumulative abnormal return is:

$$
\overline{\operatorname{CAR}\left(t_{1}, t_{2}\right)}=\frac{1}{N} \sum_{i=1}^{N} C A R_{i}\left(t_{1}, t_{2}\right)
$$

$H_{0}: C A R_{i}\left(t_{1}, t_{2}\right)=0$. When there is no correlation between each period of average abnormal returns, combining with the equation $A \hat{R}_{i t^{*}}=\frac{A R_{i t^{*}}}{\sqrt{\operatorname{var}\left(A R_{i t^{*}}\right)}}$, get the statistic by the central-limit theorem:

$$
J_{2}=\frac{\overline{C A R\left(t_{1}, t_{2}\right)}}{\sqrt{t_{2}-t_{1}+1}}\left(\frac{N(L-2)}{L-4}\right)^{\frac{1}{2}}=\frac{1}{\sqrt{t_{2}-t_{1}+1}} \sum_{i=t_{1}}^{t_{2}} \frac{1}{\sqrt{N}} \sum_{i=1}^{N} S_{i t^{*}}
$$

Under null hypothesis conditions, statistic $J_{2}$ obeys the standard normal distribution.

\subsection{Sample Selection and Data Source}

This article selected all A-share companies listed in Shanghai Stock Exchange which had announcement of issuing exchangeable bond from August 30, 2012 to 
January 30, 2017.

In order to ensure the accuracy of the empirical results, this article follows the followings when choosing the samples:

1) This article selected the listed companies of Shanghai A-share market. B shares and $\mathrm{H}$ shares were eliminated from the scope of research.

2) Remove listed companies in financial sector.

3) The sample were clean samples, excluding listed companies issued the annual financial report, quarterly financial report, the material assets reorganization, new financing plan and other major events before and after 5 days they announced to issue exchangeable bond.

4) Remove listed companies which were suspended for more than five trading days.

After filtering, this paper finally identified $17 \mathrm{~A}$-share listed companies in Shanghai Stock Exchange, selected $[-270,20]$ as the window period. Use VBA macro and Eviews to process data.

The company list and the announcement dates are from Wind Database. The stock returns are from the CSMAR Database.

\subsection{Sample Statistical Description}

There are two markets returns: one is the total market capitalization weighted rate of return, the other is the current market capitalization weighted rate of return. Table 1 is the statistical descriptions for Shanghai A-share market with the current market capitalization weighted rate of return and the total market capitalization weighted rate of return.

The Figure 1 and Figure 2 showed, no matter which kind of market return is used, China's stock market returns presented the sharp-peak and fat-tail feature, the skewness was not zero, the kurtosis was close to 6 , which suggested that it seriously did not meet the normal distribution. The median and mean were greater

Table 1. Shanghai A-share market returns under two market returns.

\begin{tabular}{ccc}
\hline & $\begin{array}{c}\text { The Shanghai A-share } \\
\text { (Market Return 1) }\end{array}$ & $\begin{array}{c}\text { The Shanghai A-share } \\
\text { (Market Return 2) }\end{array}$ \\
Mean & 0.00019 & 0.00023 \\
Median & 0.00121 & 0.00149 \\
Maximum & 0.07026 & 0.07291 \\
Minimum & -0.09228 & -0.09254 \\
Std. Dev. & 0.02010 & 0.02057 \\
Skewness & -1.03201 & -1.01755 \\
Kurtosis & 6.98768 & 6.78884 \\
Jarque-Bera & 4155.85000 & 3812.67900 \\
Probability & 0.00000 & 0.00000 \\
Sum & 0.94466 & 1.15932 \\
Sum Sq. Dev. & 1.99741 & 2.09311 \\
Observations & 4947 & 4947 \\
\hline
\end{tabular}




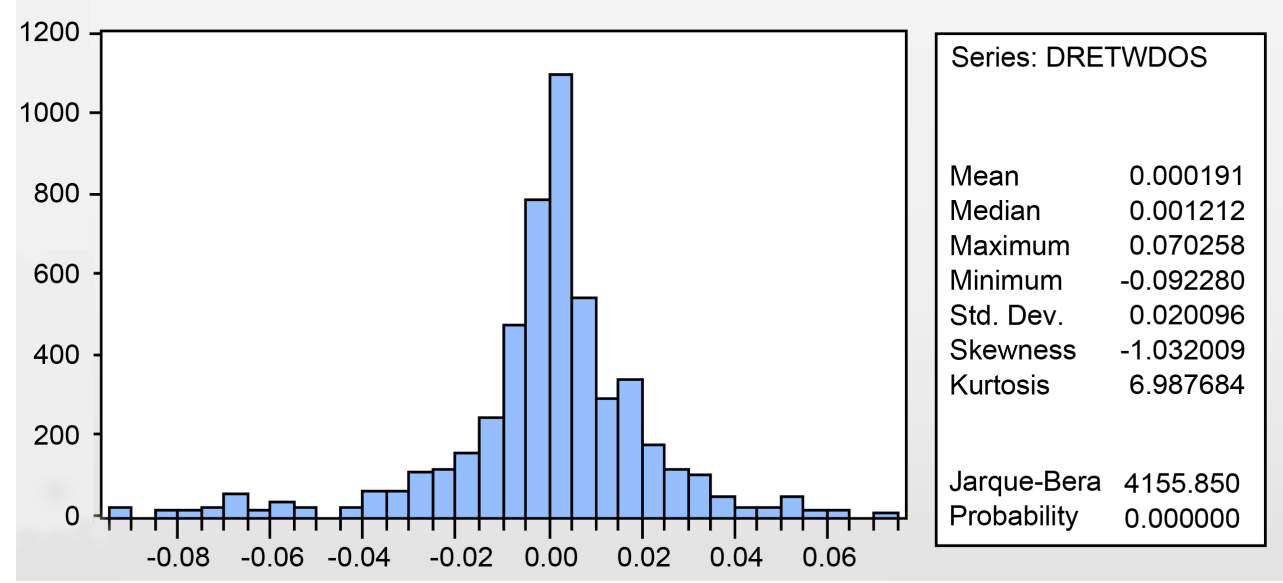

Figure 1. Shanghai A-share stock market return (current market capitalization weighted).

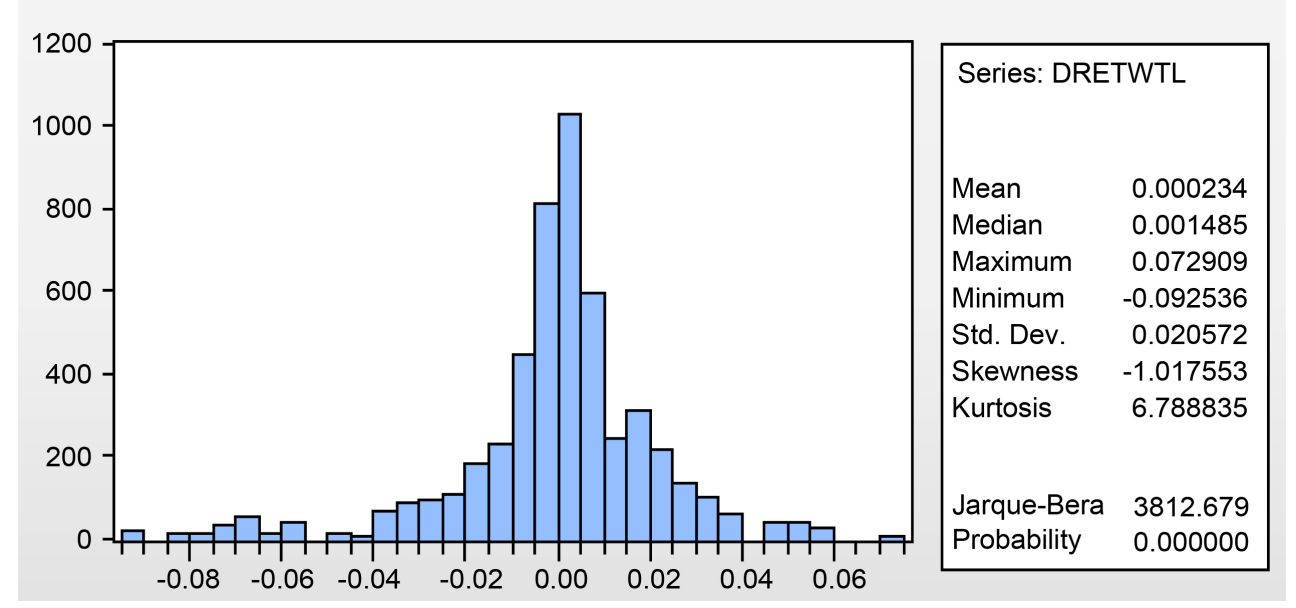

Figure 2. Shanghai A-share stock market return (total market capitalization weighted).

than zero, which indicated that the China's stock market over the past few years was a rising trend. There are a lot of restricted stocks in China's stock market, only tradable shares are greatly influenced by stock price, so this article used the daily current market capitalization weighted rate of return as the return on the market.

\subsection{Result Analysis}

The empirical results are obtained as Table 2 and Table 3.

In the window period of $(-10,20)$, ten days' ARs of Shanghai A-share market are greater than zero, and all the others are negative. In the first ten days, there are six days' ARs $<0$. And in the last 20 days, there are only six days' ARs $>0$. This suggests that, during this period, the reaction of market to the announcement of exchangeable bonds is negative. Under $5 \%$ significance level, only the -6th day shows that the AR is significant positive. And the AR is significantly greater than zero in the six days before announcement means that there may exist information leaked in advance before the announcement of exchangeable bonds in China's Shanghai A-share market. 
Table 2. AR, Statistics, $\mathrm{P}$ values and significant results of Shanghai A-share in market window period $(-10,20)$.

\begin{tabular}{|c|c|c|c|c|}
\hline Time & $\mathrm{AR}$ & Statistics & $\mathrm{P}$-value & $\begin{array}{c}\text { Significant } \\
\text { (Under the 5\% level) }\end{array}$ \\
\hline-10 & 0.00469 & 0.827754 & 0.203905 & \\
\hline-9 & -0.00458 & -0.764378 & 0.222321 & \\
\hline-8 & 0.00250 & 0.807052 & 0.209818 & \\
\hline-7 & -0.00406 & -0.742049 & 0.229029 & \\
\hline-6 & 0.01251 & 2.380389 & 0.008647 & Significant \\
\hline-5 & -0.00214 & -0.240471 & 0.404982 & \\
\hline-4 & -0.00932 & -1.344614 & 0.089375 & \\
\hline-3 & -0.00531 & -0.852092 & 0.197082 & \\
\hline-2 & -0.00825 & -1.561950 & 0.059150 & \\
\hline-1 & 0.00057 & 0.126271 & 0.449759 & \\
\hline 0 & -0.00118 & -0.330994 & 0.370325 & \\
\hline 1 & -0.00143 & -0.220795 & 0.412626 & \\
\hline 2 & 0.00560 & 0.787823 & 0.215400 & \\
\hline 3 & -0.00421 & -0.699894 & 0.241997 & \\
\hline 4 & -0.00368 & -0.632393 & 0.263565 & \\
\hline 5 & -0.00127 & -0.273136 & 0.392375 & \\
\hline 6 & -0.00290 & -0.199845 & 0.420801 & \\
\hline 7 & -0.00388 & -0.306952 & 0.379440 & \\
\hline 8 & -0.00081 & -0.132878 & 0.447145 & \\
\hline 9 & -0.00441 & -0.789922 & 0.214787 & \\
\hline 10 & -0.00225 & -0.514020 & 0.303619 & \\
\hline 11 & -0.00309 & -0.558226 & 0.288345 & \\
\hline 12 & 0.00352 & 0.700198 & 0.241902 & \\
\hline 13 & -0.00881 & -1.364312 & 0.086235 & \\
\hline 14 & 0.00096 & 0.111570 & 0.455582 & \\
\hline 15 & -0.00445 & -1.010870 & 0.156039 & \\
\hline 16 & 0.00401 & 0.788805 & 0.215113 & \\
\hline 17 & 0.00171 & 0.525697 & 0.299549 & \\
\hline 18 & -0.00118 & -0.154403 & 0.438646 & \\
\hline 19 & -0.00671 & -1.492157 & 0.067829 & \\
\hline 20 & 0.00272 & 0.361665 & 0.358801 & \\
\hline
\end{tabular}

From the perspective of the CARs, at $(-10,20)$ window period, the CARs of A-share stocks in SSE are not significant. That is, the effect of announcement has little effect on the stock market in this period. It shows that the Shanghai A-share market efficiency is higher, and the effect of issuing announcement will not cause too much changes on the stock price. The market can digest the publication information quickly.

The above Table 4 shows that the CARs $>0$ only appeared in the window ( 0 , 2 ), while it is less than zero in the other window period. This result also indicates 
Table 3. CAR, Statistics, $\mathrm{P}$ values and significant results of Shanghai A-share in each window period.

\begin{tabular}{ccccc}
\hline Event Window & CAR & Statistics & P-value & $\begin{array}{c}\text { Significant } \\
\text { (Under the 5\% level) }\end{array}$ \\
\hline$(-10,20)$ & -0.04513 & -0.03355 & 0.486618 & Non-significant \\
0 & -0.00118 & -0.00487 & 0.498055 & Non-significant \\
$(-1,0)$ & -0.00061 & -0.00179 & 0.499288 & Non-significant \\
$(0,1)$ & -0.00261 & -0.00765 & 0.49695 & Non-significant \\
$(-1,1)$ & -0.00204 & -0.00489 & 0.49805 & Non-significant \\
$(-2,0)$ & -0.00886 & -0.02118 & 0.491551 & Non-significant \\
$(0,2)$ & 0.00298 & 0.00713 & 0.497156 & Non-significant \\
$(-2,2)$ & -0.00470 & -0.0087 & 0.496528 & Non-significant \\
\hline
\end{tabular}

Table 4. Summary information of CAR in the Shanghai a-share market.

\begin{tabular}{ccccccccc}
\hline & $(-10,20)$ & 0 & $(-1,0)$ & $(0,1)$ & $(-1,1)$ & $(-2,0)$ & $(0,2)$ & $(-2,2)$ \\
\hline Mean & -0.04513 & -0.00118 & -0.00061 & -0.00261 & -0.00204 & -0.00886 & 0.00298 & -0.00470 \\
Std. Error & 0.02648 & 0.00357 & 0.00554 & 0.00410 & 0.00588 & 0.00725 & 0.00611 & 0.00855 \\
Median & -0.04456 & -0.00182 & -0.00362 & -0.00078 & -0.00309 & -0.00603 & 0.00034 & -0.00285 \\
Mode & -0.04456 & -0.00182 & 0.01569 & 0.00166 & 0.01918 & 0.00662 & 0.01945 & 0.02789 \\
Std. Dev. & 0.10918 & 0.01472 & 0.02284 & 0.01691 & 0.02425 & 0.02990 & 0.02519 & 0.03526 \\
Variance & 0.01192 & 0.00022 & 0.00052 & 0.00029 & 0.00059 & 0.00089 & 0.00063 & 0.00124 \\
Kurtosis & 0.27726 & 2.48587 & 1.48823 & 3.39942 & 2.58359 & 0.58306 & -0.23531 & -0.12607 \\
Skewness & -0.06280 & 0.88279 & 0.80850 & 0.83260 & 1.08538 & 0.00861 & 0.09077 & 0.12941 \\
Minimum & -0.25801 & -0.02803 & -0.03401 & -0.03282 & -0.03598 & -0.05965 & -0.04196 & -0.07000 \\
Maximum & 0.15475 & 0.03804 & 0.05852 & 0.04442 & 0.06490 & 0.05805 & 0.04408 & 0.06272 \\
Summation & -0.76722 & -0.02002 & -0.01037 & -0.04441 & -0.03476 & -0.15068 & 0.05072 & -0.07994 \\
Observations & 17 & 17 & 17 & 17 & 17 & 17 & 17 & 17 \\
\hline
\end{tabular}

that the reaction of the market for the Shanghai A-share listed companies issuing exchangeable bonds announcement is negative. The CARs are not significant in the window period, which suggest that the impact of issuing announcement on the market is not big.

\section{The Conclusions and Policy Recommendations}

The emergence and application of China's exchangeable bonds is greatly later than abroad. Considering from the external environment, China is in the process of reforming and opening up. The openness and efficiency of the capital market is gradually enhanced. At first, the exchangeable bonds are hard to enter the market in China. Now, it has developed to release several exchangeable bonds every month, only three and a half years after its first release. To meet the financing needs of different issuers, the exchangeable bonds have spawned many types in China's market. We should not only see the advance of China's capital market, but also find its disadvantages. Discovered by empirical results in this 
paper, the Shanghai A-share market is efficient. The hypothesis that the ARs $=0$ has passed after the announcement of exchangeable bonds. It shows that the announcement effect on the two markets on the event day is not significant. But the Shanghai A-share market's ARs is significantly positive in the -6th day. However, it soon subsides, with no lag reaction later. In the efficient market, the market will immediately begin to digest and absorb the news once they have been issued. So, the time of disclose issuing announcement will only affect the stock at that point, and the stock abnormal returns are only related to the news. Studies on both China and abroad also satisfy the weak validity of stock market, the price includes all historical information, and we cannot get excess returns through technical analysis.

Based on the analysis above, this article puts forward the following suggestions. First of all, for the Shanghai A-share market, we need to further improve its effectiveness, further refine the trading rules and create more financial derivatives for the demander. In addition, we also need to develop and optimize the related laws and regulations. Due to the new characteristics of modern finance, perhaps the smallest butterfly flaps its wings could also bring unexpected consequences. Therefore, the Chinese government needs to strengthen the supervision, making the financial market standardization and developing towards the good direction.

\section{References}

[1] Frank, H.E. (1984) Two Agency-Cost Explanations of Dividends. American Economic Review, 74, 650-659.

[2] Flannery, M.J. (1986). Asymmetric Information and Risky Debt Maturity Choice. The Journal of Finance, 41, 19-37. https://doi.org/10.1111/j.1540-6261.1986.tb04489.x

[3] Kale, J.R. and Noe, T.H. (2004) Risky Debt Maturity Choice in a Sequential Game Equilibrium. Journal of Financial Research, 13, 155-165. https://doi.org/10.1111/j.1475-6803.1990.tb00545.x

[4] Datta, S., Iskandar, D.M. and Raman, K. (2000) Debt Structure Adjustments and Long-Run Stock Price Performance. SSRN Electronic Journal, 9, 427-453. https://doi.org/10.2139/ssrn.232288

[5] Berlin, M. and Loeys, J. (1988) Bond Covenants and Delegated Monitoring. The Journal of Finance, 43, 397-412. https://doi.org/10.1111/j.1540-6261.1988.tb03946.x

[6] Diamond, D.W. (1991) Debt Maturity Structure and Liquidity Risk. Quarterly Journal of Economics, 106, 709-737. https://doi.org/10.2307/2937924

[7] Myers, S.C. and Majluf, N.S. (1984) Corporate Financing and Investment Decisions When Firms Have Information That Investors Do Not Have. Social Science Electronic Publishing, 13, 187-221. https://doi.org/10.1016/0304-405x(84)90023-0

[8] Shang, Y.H. (2009) Corporate Bonds of the Corporate Governance Effect Analysis. Journal of Accounting Research, No. 8, 47-49.

[9] Zhao C. (2016). China's Listed Companies Corporate Bond Issuance Announcement Effect Research. Business, No. 4, 180-181.

[10] Abhyankar, A. and Dunning, A. (1999) Wealth Effects of Convertible Bond and Convertible Preference Share Issues: An Empirical Analysis of the UK Market. 
Journal of Banking \& Finance, 23, 1043-1065.

https://doi.org/10.1016/S0378-4266(99)00002-3

[11] Dutordoir, M. and Gucht, L.V.D. (2006) Are There Windows of Opportunity for Convertible Debt Issuance? Evidence for Western Europe. Journal of Banking \& Finance, 31, 2828-2846. https://doi.org/10.1016/j.jbankfin.2007.02.010

[12] Ammann, M., Fehr, M. and Seiz, R. (2006) New Evidence on the Announcement Effect of Convertible and Exchangeable Bonds. SSRN Electronic Journal, 16, 43-63. https://doi.org/10.1016/j.mulfin.2005.03.001

[13] Kang, J.K. and Stulz, R.M. (1996) How Different is Japanese Corporate Finance? An Investigation of the Information Content of New Security Issues. Review of Financial Studies, 9, 109-139. https://doi.org/10.1093/rfs/9.1.109

[14] Roon, F.D. and Veld, C. (1995) Announcement Effects of Convertible Bond Loans and Warrant-Bond Loans: An Empirical Analysis for the Dutch Market. Journal of Banking \& Finance, 22, 1481-1506. https://doi.org/10.1016/S0378-4266(98)00055-7

[15] Dutordoir, M., Li, H., Liu, F.H. and Verwijmeren, P. (2015) Convertible Bond Announcement Effects: Why Is Japan Different? Journal of Corporate Finance, 37, 76-92. https://doi.org/10.1016/j.jcorpfin.2015.12.006

[16] Ammann, M., Blickle, K. and Ehmann, C. (2017) Announcement Effects of Contingent Convertible Securities: Evidence from the Global Banking Industry. European Financial Management, 23, 127-152. https://doi.org/10.1111/eufm.12092

[17] Wang, H.Y. and Xia, X.P. (2004) A Convertible Bond Issue Empirical Study of the Impact of Stock Price. Journal of South-Central University for Nationalities (Natural Science Edition), 23, 106-109.

[18] Luo, Y., Wang, G.S. and Zhang, Z.C. (2006) The Chinese Market: An Empirical Study of the Convertible Bond Announcement Effects. Journal of East China Economic Management, 20, 142-146.

[19] Chen, H. and Li, Y.X. (2005) The Issue of Domestic Convertible Bonds on the Company's Stock Price Impact Study. Journal of Liaoning Economy, No. 8, 62-63.

[20] Tao, Z.C. (2007) The Convertible Bond Announcement Effects Research in China. Journal of Business Culture (Academic), No. 5, 34.

[21] Xu, X.Q. (2010) Bond Financing Effects on Corporate Performance-From the Empirical Study of Listed Companies. Journal of Accounting Communications, No. 24, 113-116.

[22] Fu, L.M., Wan, D.F. and Zhang, Y.H. (2011) New License: Optimal Sequence Financing Theory and Corporate Bonds, Convertible Bonds to Raise Equity Announcement Effect of Comparative Analysis. Financial Review, 3, 101-114.

[23] Wang, B., Miao, J. and Wang, F. (2014) Research on the Announcement Effects of the Convertible Bonds in the A-Share Market of China. Modern Economy, 5, 83-88. https://doi.org/10.4236/me.2014.54033 
Submit or recommend next manuscript to SCIRP and we will provide best service for you:

Accepting pre-submission inquiries through Email, Facebook, LinkedIn, Twitter, etc. A wide selection of journals (inclusive of 9 subjects, more than 200 journals)

Providing 24-hour high-quality service

User-friendly online submission system

Fair and swift peer-review system

Efficient typesetting and proofreading procedure

Display of the result of downloads and visits, as well as the number of cited articles Maximum dissemination of your research work

Submit your manuscript at: http://papersubmission.scirp.org/

Or contact ti@scirp.org 